Historic, Archive Document

Do not assume content reflects current scientific knowledge, policies, or practices. 

Seedling Description Price

Astrophytum asterias,

2 inch diameter................ $\$ 2.00$

Astrophytum myriostigma

1 inch high....................75

Cephalocereus senilis,

6 months, 50c; 1 year........... .75

Echinocactus ingens, 1 year......... $\quad .75$

Echinocactus Grusonii, 1 year...... $\quad .50$

Lophocereus Schottii, $3 / 4$-inch........ .35

Opuntia Rafinesquei, hardy 4 -in.... .25

Opuntia ursina (long white haired)

4 -inch rooted cuttings............. .35

\section{SUCCULENT SEEDS}

Name

Aloe variegata..............10

Echeveria Desmetiana...........50

Echeveria setosa.............50

Euphorbia aphylla............. 2

Euphcrbia atropurpurea........ 2

Euphorbia balsamifera......... 5

Euphcrbia bupleurifolia.......... 1

Euphorbia canariensis ........25

Euphorbia gorgonis............ 1

Euphorbia Hermentiana ........ 5

Euphrobia meloformis.......... 1

Euphorbia cbesa ............. 5

Euphorbia Regis-Jubae ........ 2

Mesemb. Lithops bella.........25

Mesemb. Lithops Lesliei........25

Mesemb. Lithops Mundtii.......25

Mesemb. Pleiospilos simulans....25

Rochea falcata...............25

Tavaresia grandiflora..........10

Cacti in the Home, Illustrated,

48 pages. Postpaid............

Our Native Cacti (Ethel Bailey

Higgins). Postpaid.............

The Cactus Book

(Dr. A. D. Houghton) .

Dealers who are interested in large quant prices, which we believe are the lowest in the U. S. A.
Seedling

Description

Pachycereus pecten-aboriginum

$11 / 4$ inch......................... .25

Peniocereus Johnstonii,

2 inch, 50c; 4 inch...... .........1.00

Agave americana variegata,

$21 / 2$ inch, 25c; 3 inch.............. .35

Agave Victoriae-Reginae,

2 in pot...

Echeveria Dases.... .35

Echeveria metallica, 3 inch.........

Euphorbia lactea,

5 inch rooted cuttings............. 50

Rochea falcata, 2 inch............. .50

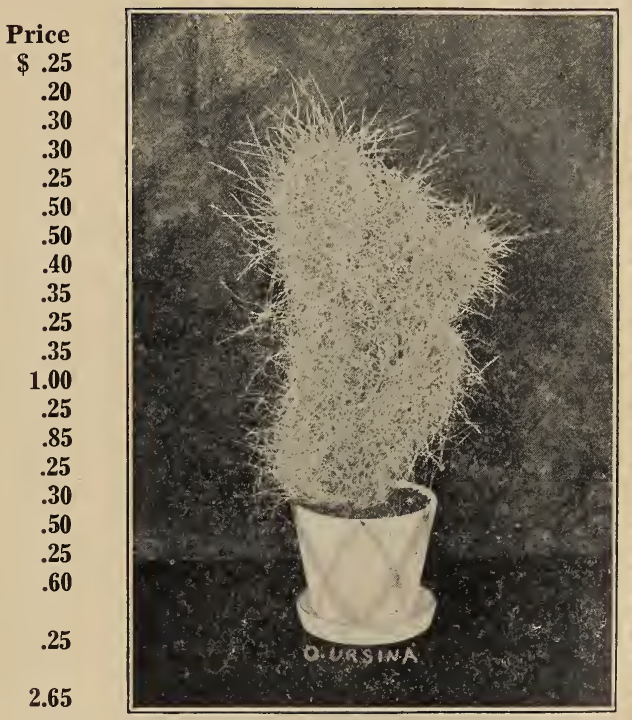

O. URSINA

OUR ILLUSTRATED PRICE LIST FREE.

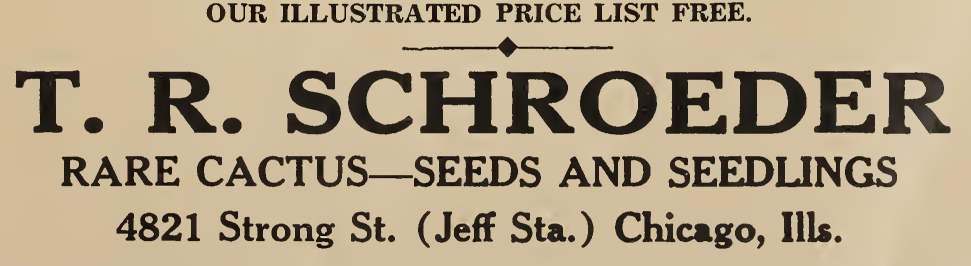





\section{Instructions for Raising Cacti from Seeds}

Sow in March, April or May as later sowings generally. prove less advantageous and frequently cause great losses in winter-unless you use special equipment.

Use shallow pans about 2 inches high and of 5 to 6 inches in diameter. The bottom of these pans is filled with cinders or broken clay pottery to $1-3$, and the other $2-3$ with a mixture of soil consisting of 2-3 good peat, leafmould and 1-3 coarse sand. Level the soil with a flat piece of wood, and sow the seed evenly. Sift fine soil over the seeds, only just enough to cover. The seeds are now gently pressed in with a round piece of board, leaving room between soil and rim of pan of about $1 / 2$ inch. The soil may now be properly watered with a very fine spray. Moistening may also be done by putting the pan into water, to half of its height, until the surface begins to get damp. The pans are then placed in frame with glass cover, with bottom heat of about 65 to 75 degrees and covered in, up to their rims, with moss. The frame must be air-tight, and shaded with paper or other thin material against hot sunshine preventing the soil from drying too fast. Dry pans must be watered every day. Some varieties germinate within a few days, while others require longer, sometimes several months. Mammillarias and Echinocacti germinate quickest, whereas the Cereus, Pilocereus and Opuntia sorts require a longer time. It is essential and very important that all seeds are kept in even temperature and even dampness; in this way they will germinate best and easiest. Ten days or three weeks after germination the young seedlings are picked out in other pans with soil as above indicated. A pointed piece of wood of the thickness of a pencil may be used for this purpose and small holes, $1 / 2$ inch apart, are dipped in the surface. The Seedlings are lifted with a small wooden fork from the Seedpan, then placed in the holes and the soil gently pressed on round the roots with the pointed wood, taking care not to place them either too deep or too shallow. After transplanting, the small plants are very carefully watered to prevent washing them out.

The pans, now replaced into frame, are shaded and aired according to weather. Thus treated the plants will soon be strong enough to stand the winter, and may be placed close to light in a moderately warm room. To prevent the plants getting too dry, I recommend to water once a week with water luke-warm. In a greenhouse this will not be necessary so often, the air never becoming so dry. At any rate culture of Cacti from seed is well worth trying and it is highly interesting to watch the little plants in their different stages of growth. A magnifying-glass for this purpose is very handy.

Pans, as well as soil, can be supplied by me at a small cost and I shall be pleased to hear of your results.

\section{T. R. SCHROEDER}

Rare Cactus-Seeds and Seedlings

4821 Strong St. (Jeff. Sta.) :: $\quad$ Chicago, Ill., U. S. A. 



\section{HOW TO PLANT CACTI}

Use $1 / 3$ coarse sand, commonly called torpedo sand, and $\% / 3$ loose soil, leaf mold or other good soil that will not bake hard. A pinch of air slacked lime may be added to sweeten the soil, and if possible, include a little charcoal in the mixture. The charcoal will help prevent decay of the plant.

Watering depends entirely on the condition of the cactus. If the roots are fresh and the tiny feeder roots intact, you may water immediately and regularly. If the roots are dried out or broken off, water must be used sparingly until the cactus has formed new roots. This will take place without. watering, after being planted.

After several weeks when new roots have grown, water may be applied sparingly at first, and the quantity increased each week for four or five weeks, then the soil can be kept slightly damp.

If your container has no drainage, watch your soil closely that it is not too wet. Too much water may cause the cactus to rot.

Cacti plants need less attention than other plants to survive. They will live months and even years without water, BUT THEY WILL NOT GROW OR BLOOM WITHOUT MOISTURE AND SUNSHINE.

Your dealer can supply you with a 48-page illustrate booklet called "CACTI IN THE HOME," at 25 cents. This gives you complete instructions how to care for your cacti from seed to the mature plant. If he is unable to supply it send 25 cents in stamps to the address below and it will be mailed, postpaid.

\section{T. R. SCHROEDER}

\section{Rare Cactus - Seeds and Seedlings} 4821 STRONG ST. (Jeff. Station) CHICAGO, ILL., U.S.A. 
